\title{
Legal Protection on Local Employee Rights Related with Foreign Mission Immunity in Indonesia
}

\author{
Sefriani
}

\begin{abstract}
On 2013, Indonesian court had pronounced two progressive sentences which were distinct to identical sentences on previous years. Both sentences declared that Brazilian Embassy and USA consulate were culpable upon deposing one of their local employee without paying severance money as regulated by Indonesian Labor Laws. The court had disposed the embassy and the consulate's immunity claim against any Indonesian legal proceedings. Although those sentences were lacking of international law argument, they had serious concern on Human Rights protection enforcement on local employee who possesses weaker standing than the employer. They were also in tune with European court sentences which have discarded absolute immunity.
\end{abstract}

Index Terms - Immunity and local employee.

\section{INTRODUCTION}

State immunity also diplomatic immunity are not a brand-new topic in international law. The customary international law since centuries ago had recognized and implemented it. Those immunities rest upon two principles are Par in parem non habet jurisdiction and non intervention [1]. The first principle is concerned with the status of equality attaching to the independent sovereign. Legal persons of equal standing cannot have their disputes settled in the courts of one of them. This principle is satisfied if a sovereign state waives its immunity. The consent given upholds the status of equality. If there is a subject-matter over which the national courts of the other state may properly exercise jurisdiction in rem or if there is a basis for acquiring jurisdiction in personam, then jurisdiction follows consent. The second principle on which immunity is based is that of non-intervention in the internal affairs of other states. This produces an area of issues which are in essence non justiciable. It is difficult to catalogue such issues but the nature of the subject matter will lead a municipal court to accept that it is not an appropriate forum and can do nothing useful or effective. A good example would be the immunity of arbitrations between states from the jurisdiction of the state in which the arbitration takes place. The principle of non-intervention overlaps with the Act of State doctrine as a doctrine of municipal law [2].

The development of state and diplomatic immunity had been flourished rapidly from absolute immunity became restrictive immunity [3]. Immunity is only applicable for state activities that category to jure imperii or public activity instead of jure gestionis or commercial activity. Acts jure imperil were those acts of a particularly sovereign or

Manuscript received April 14, 2014; revised August 2, 2014.

Sefriani is with the International Law at Faculty of Law, Islamic University of Indonesia (e-mail: Sefri_ani@yahoo.com). governmental nature which no private person would ordinarily perform, whereas acts jure gestionis were those acts which, although performed by governments, were or could be equally performed by private persons. Although this distinction had originated in European civil law countries, it was accepted by common law courts in the 1970s. The distinction between sovereign and commercial acts was first applied in the context of more obvious commercial transactions such as contracts for the sale of goods or loan agreements to impose liability on foreign

States which would not have been possible under the previous doctrine of absolute immunity. However, the implementation of immunity is still not in tune and inconsistent in the practice level. The implementation of both immunity types depends on state's interests [4].

This following article will discusses both progressive sentences of Indonesian court deal with diplomatic and consular immunity issues especially related with the termination of employment of two local staff at the Brazilian Embassy in Jakarta and the US Consulate in Medan.. First sentence is Supreme Court Sentence No. 673K/Pdt.Sus/2012 on industrial relation dispute of Indra Taufik Djafar vs US Consulate in Medan and US Embassy in Jakarta. This dispute was begun when the US Consulate in Medan unilaterally sacked Indra, Indonesian citizen, who had been worked in the consulate for more than 11 years and 8 months from his job without following proper procedure as regulated in Indonesia Labor Laws No. 13 of years 2003. Initially, this case had been submitted to The Medan Office agency of Labor in Medan which suggested the US Consulate to pay severance money to Indra for IDR. 175,565,600 [5].

Indra filed a lawsuit with the Medan Industrial Relations Court (PHI) against the embassies, demanding the payments since US consulate refuse to pat those payment. The industrial Relation Court passed sentence No. 142/G/2011/PHI. Mdn on 26 April 2012 which declared that the lawsuit was inadmissible. Industrial Relation court in Medan had argued in their sentence that US Consulate in Medan could not hold defendant position in this suit since it did not have legal personality which is distinct with their home country. As result, the court sentenced Indra to pay the case cost for IDR 686, 000, 00. Dissatisfied with the sentence, Indra submitted the lawsuit to Supreme Court.

In their sentence, Supreme Court argued that Medan Industrial Labor Court sentence had been conflicting against basic principles of Indonesian Relation Law as stated on article 4 of clause 1) and clause 2) and article 5 of clause 1) and clause 2) of Laws No. 48 of years 2009. Those articles stated that: [6]

1) The court shall adjudicate any people and enforce the justice fairly and indiscriminately; 
2) The court shall help any justice seeker and shall attempt to solve any hindrance in order to achieve simple court proceeding that is fast, efficient and affordable;

3) Judge and Constitutional Judge shall exploring, adhering and comprehending law norms and justice that living in society.

4) Judge and Constitutional Judge shall possess integrity, noble personality, honest, fair, professional and experienced in legal practice.

The Supreme Court stated that since the matter brought is essentially the termination of employment which took place in the territory of Indonesia, therefore, Law No. 13 of 2003 on labor should be applied [7]. Base on The Indonesian Law, The Supreme Court imposed US Consulate to pay Indra severance money for IDR. 151.597.600, 00, Besides, US Consulate was also obliged to pay case cost by Supreme Court for the entire level of court proceedings for IDR 500, $000[8]$.

The second sentence which become object of discussion in this article is Jakarta Industrial Relation Court sentence that imposed Brazil Embassy to pay severance money to Luis Pereira, local employee who had been fired by the Embassy. The court argue that Brazilian diplomatic immunity shall be removed since the employment contract between Luis Pereira and the embassy choose Indonesian Law as applicable law. Based on Indonesia Labor Law, Pereira deserved to receive compensation for IDR 485,000,000. The court argued that employee's right shall be protected against any violation. The Embassy cannot hide itself behind their diplomatic immunity after violating employee's rights [9].

Both of sentences which delivered at 2013 resulted objection from Brazil Embassy and US Consulate. They argue Indonesia has no jurisdiction to adjudicate them. The employer, a consular or diplomatic functional officer, shall not be amenable to jurisdiction of the Indonesia's judicial or administrative authorities. They also submitted that the embassy or consulate has no separate legal personality from the sending State and therefore could not be sued in an Indonesian domestic court [10].

Considering that there was conflicting perspectives of Indonesian supreme court vs Brazil Embassy and US Consulate, this article attempts to analyze the issue of foreign mission immunity deal with employment ontact which involved the local employee. This article is segmented into three sections, they are: introduction, the review on both Indonesian court sentences from the perspective of human rights law and international law section and conclusion section.

\section{Progressive SENTENCES OF INDONESIAN COURT}

Cases as discussed previously are evidence that Indonesia court is able to produce courageous and progressive sentences which concern on human rights protection of local employee against foreign mission as stronger legal subject that possess diplomatic immunity based on international law. On previous years, almost all sentences which was pronounced by Indonesia court always granted the jurisdictional immunity toward foreign mission. The lawsuit of Samsir Iskandar vs US Embassy, for example, showed that the court declared having no authority to adjudicate the embassy when this institution was fail to pay rent on Samsir Iskandar's house that was used as US Embassy office since they possess diplomatic immunity[11]. Another case which involved Saudi Arabian Embassy showed that Supreme Court declared that the Embassy was immune from any charges or lawsuit before national court including the issue of arable land or occupied land or any issue related to land. Those examples point out that Indonesia court embraced absolute immunity which granted adjudicative immunity to embassy in all cases including civil case. The rights of individual who has rented their house and land to the foreign embassy is ignored. As result, they had to pay the cost case instead of receiving compensation.

The supreme court sentences at 2013 exposed contrast with sentences on previous years concerned on civil rights that always applied absolute immunity toward foreign permanent mission. When foreign permanent mission signed employment contract with any person, in which employment contract is categorized as civil relation, the diplomatic immunity shall be removed. If it is not removed, the position of both parties will be imbalance [12] and it potentially violates local employee's rights as the party with weak standing since foreign mission will not be responsible upon the loss of local employee by hiding behind its diplomatic immunity. This condition is definitely not apt with the development of labor movement that promotes labor rights protection and honor based on human rights law.

It is right that Immunity for permanent foreign mission along with their officials had been recognized since centuries ago [13]. There are some theories which attempt to elaborate reason of diplomatic immunity is awarded to foreign mission. Those theories are Sacredness of Ambassadors theory, Extraterritoriality theory [14], Representatives of Foreign States theory and Functional Necessity theory [15]. Article 43 of the Vienna Convention on Consular Relations 1963 clearly provides that a contract concluded by a consular officer as an agent of the sending state shall be immune from the jurisdiction of receiving states.

In other side Article 11 of United Nations Convention on Jurisdictional Immunities of States and Their Property 2004 stipulated that:

"Unless otherwise agreed between the States concerned, a State cannot invoke immunity from jurisdiction before a court of another State which is otherwise competent in a proceeding which relates to a contract of employment between the State and an individual for work performed or to be performed, in whole or in part, in the territory of that other State"

Furthermore, this article mentioned that this paragraph does not apply if:

1) The employee has been recruited to perform particular functions in the exercise of governmental authority;

2) The employee is:

- Diplomatic agent, as defined in the Vienna Convention on Diplomatic Relations of 1961;

- Consular officer, as defined in the Vienna Convention on Consular Relations of 1963;

- A member of the diplomatic staff of a permanent mission to an international organization or of a special mission, or is recruited to represent a State at an international conference; or 
- Any other person enjoying diplomatic immunity;

3) The subject-matter of the proceeding is the recruitment, renewal of employment or reinstatement of an individual;

4) The subject-matter of the proceeding is the dismissal or termination of employment of an individual and, as determined by the head of State, the head of Government or the Minister for Foreign Affairs of the employer State, such a proceeding would interfere with the security interests of that State;

5) The employee is a national of the employer State at the time when the proceeding is instituted, unless this person has the permanent residence in the State of the forum; or

6) The employer State and the employee have otherwise agreed in writing, subject to any considerations of public policy conferring on the courts of the State of the forum exclusive jurisdiction by reason of the subject-matter of the proceeding.

This provision points out that employment contract between permanent foreign mission and the local employee is not subject to diplomatic immunity law [16]. The progressive sentence of Indonesia court on industrial relation is not an amazing sentence compared to similar cases that occurred in other countries. The practice of the vast majority of European countries of the civil law tradition in regard to employment at diplomatic and consular missions now clearly supports the restrictive immunity theory. To some extent this is a legacy of the Basle Convention, which has been ratified and adopted into municipal law by the following countries: Austria, Switzerland, the Netherlands, Belgium and Cyprus. The Basle Convention specifically provides for employment contracts in Article 5, which creates a presumption of non-immunity where the contract is to be performed in the forum State .Immunity is, however, restored where the employee is a national of the foreign State at the time of the proceedings or was not a national or permanent resident of the forum at the time of entering into the contract [17].

The progressive sentence of Indonesia court on industrial relation is not an amazing sentence compared to similar cases that occurred in other countries. In developed countries, judicial decisions on this matter have been developing rapidly. European countries have deviated from absolute immunity approach and turn to a more restrictive approach concerning labor issues. Restrictive immunity requires states to differentiate the treatment toward an embassy or consulate on one hand and that of diplomats or consuls on the other. European countries treat embassies or consulates as ordinary business entities. Therefore, there are certain conditions that mean both embassies and consulates are public institutions not entitled to immunity. Those conditions depend on each legal system, but only to the extent permitted by international law. Indonesia Embassy was sentenced to pay severance money to Portuguese and Italian employees by Portugal and Italian courts [18].

The Netherlands, which ratified the Basle Convention in 1988 , is an example of a State which has changed its attitude to employment contracts at diplomatic and consular missions and now embraces a policy of restrictive immunity. As recently as 1978 , however, an approach of absolute immunity based on the plac or location of employment was adopted. In the Gootjescase, 1it was held that Belgium was entitled to immunity from a suit by a Dutch national employed in the administrative service of the Belgian consulate on the basis that a consulate was "a public body in which the state of Belgium was acting in a public capacity" [19].

Other example, on July 19, 2012, in the case concerning the Algerian Embassy's driver in Berlin, the European court once declared that the Embassy as the employer has to be treated as an establishment when employing a person, provided that the job carried out is not an exercise of public authority. In Austria, the domestic labor law will not prevail when the employment contract entered into is between a diplomat and an individual who is not a national of Austria, or otherwise not holding a permanent resident permit. These conditions are recognized by international law [19]. On the other hand, labor law of receiving state should be applied when the employment relationship is conducted by the Embassy or Consulate with local employee. Such conditions are recognized by international law. In short, the sentences which were produced by court in European countries clearly stipulated certain conditions that disabling the foreign mission to put their diplomatic immunity into effect and those sentences were apt to constraint norms which have been set by international law [19]. Those examples shows that recent days many countries applied restrictive immunities instead of absolute immunity. The restrictive immunity differs act of state into commercial act and public act. Immunity is only granted on state's non-commercial act or public act [20]. State which conducted commercial act is considered waive its immunity [21]. The restrictive immunity also differentiate the treatment toward an embassy or consulate on one hand and that of diplomats or consuls on the other. Almost all Western and industrial countries accept restricted immunity doctrine [22].

\section{CONCLUSION}

Both progressive Indonesian court sentences as previously discussed have not delivered conclusion that Indonesia court has shifted its paradigm from absolute immunity paradigm into restrictive immunity paradigm. It happens since the judge's legal arguments were vaguely formed. However, they deserve big appreciation for their courageous decision to ignore immunity claim from foreign mission in civil cases and it was a giant leap for Indonesian court since they did what national court of developed countries did on diplomatic immunity. As final conclusion, it confirms that absolute immunity become myth; individual and states may be equal before the courts; the increasing needs of accountability of states towards individuals and good governance needs no immunity

\section{ACKNOWLEDGMENT}

The author would like to express gratitude to Law School of Islamic University of Indonesia which facilitated the author to do this research.

\section{REFERENCES}

[1] A. Kaczorowska, Public International Law, Old Bailey Press, London, p. 139,2002

[2] I. Brownlie, The Law and Politics of Foreign Sovereign Immunity, 102 Am. Soc'y Int'1 L. Proc. 106, p. 106. 
[3] Y. B. Ardiwisastra, Imunitas Kedaulatan Negara di Forum Pengadilan Asing, Alumni, Bandung, 1999, p.34.

[4] US and Brazil are examples. Both countries implemented restricted immunity for foreign embassy which conducting layoff to local employee. Court Case: Brazil to Use TAP Airbus as Pawn for Legal Proceedings. [Online]. Available: http://www.portugaldailyview.com/whats-new/brazil-to-use-tap-airbu s-as-pawn-for-legal-proceedings. However, when they encounter identical case in Indonesia, they claim for absolute immunity since they were has immunity before Indonesian court and could not subjected to Indonesia labor laws. [Online]. Available: http://news.detik.com/read/2014/01/10/140204/2464009/10/kedubes-a s-di-indonesia-belum-patuhi-putusan-ma-di-kasus-ketenagakerjaan?9 922032

[5] Indonesian Supreme Court Decision Nomor 673 K/Pdt. Sus/2012, p. 4.

[6] Indonesian Supreme Court Decision Nomor 673 K/Pdt. Sus/2012, pp. 9-10.

[7] D. Agusman and Y. Pribadhie, "Diplomats don't always enjoy immunity," The Jakarta Post, February 6, 2014

[8] Indonesian Supreme Court Decision Nomor 673 K/Pdt. Sus/2012, p. 13

[9] Kedubes Brazil Dihukum Membayar Pesangon. [Online]. Available: http://www.hukumonline.com/berita/baca/lt51223fc28ac1c/kedubes-b razil-dihukum-membayar-pesangon

[10] Damos Agusman and Yanuar Pribadhie, supra note 7.

[11] S. Gautama, Aneka Masalah hukum perdata Internasional (Himpunan Karangan Hukum Perdata Internasional), Alumni, Bandung, p. 15, 1985.

[12] Yudha Bhakti Ardiwisastra, supra note 3, at. 44.

[13] Sumaryo Suryokusumo, Hukum Diplomatik Teori dan Kasus, Alumni, Bandung, 1995.

[14] Commentary (No name), "A new regime of diplomatic immunity: the diplomatic relations act of 1978," 54 Tul. L. Rev. 661, p. 664, 1980

[15] L. J. Shapiro, Foreign Relations Law: Modern Developments in Diplomatic Immunity, 1989 Ann. Surv. Am. L. 281, p. 282, 1990.
[16] D. P. Stewart, Current Development: The UN Convention on Jurisdictional Immunities of States and Their Property, 99 Am. J. Int'1 L., p.124, 2005.

[17] G. Richard, "State immunity in employment matters," I. C. L. Q., vol 46, no. 1, pp. 81-124, 1997.

[18] Damos Agusman and Yanuar Pribadhie, supra note 10.

[19] Richard Ganett, p. 94

[20] P. Malanczuk, Akehurst's Modern Introduction to International Law, $7^{\text {th }}$ edition, Routledge, New York, hlm.119, see also F. M Maniruzzaman, 2005, "State enterprise arbitration and sovereign immunity issue: a look at recent trends," 60 -Oct Disp Resol. J77., at. $85,1997$.

[21] M. E. Wiesinger. (2006). State Immunity from Enforcement Measures. University of Vienna. [Online]. Available: http://intlaw.univie.ac.at/fileadmin/user_upload/int_beziehungen/Inter netpubl/wiesinger.pdf

[22] A Dickinson et al., State Immunity: Selected Materials and Commentar, Martinus Nijhoff Publishers, p.73, 2004.

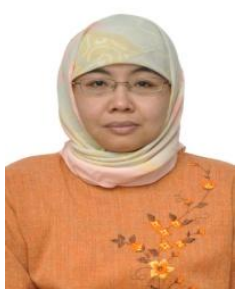

Sefriani was born in Temanggung, on September 6 1969. She graduated from Faculty of Law, Gadjah Mada University in 1993 (Undergraduate Study), Faculty of Law, Padjadjaran University in 2001 (Postgraduate Study), and Faculty of Law, Gadjah Mada University in 2012 (Postgraduate Study).

She works at Faculty of Law Islamic University of Indonesia as lecturer since 1993. She wrote a book about Introduction of International Law in 2012 and got published by Raja Grafindo Persada publishing. She actively published her articles and journals into acredite journal/publishing in Indonesia. She also actively conducted research and attended various international and national workshops and seminars. Her research interests include international dispute resolution law, international law, human rights law, and international organization law 